\title{
STRATEGI PEMASARAN PRODUK PEPAYA SUNFRESH JENIS CALIFORNIA GRADING B DAN C DI PASAR TRADISIONAL KAWASAN JABOTABEK 2012-2014
}

\author{
Aprihatiningrum Hidayati \\ Program Studi S2 MM Wijawiyata Manajemen \\ Sekolah Tinggi Manajemen PPM \\ Pepey Riawati Kurnia \\ Sekolah Tinggi Manajemen PPM
}

\begin{abstract}
Perusahaan dalam penelitian ini adalah distributor buah segar berskala nasional. Saat ini perusahaan sedang dalam tahap pertumbuhan. Untuk itu diperlukan suatu strategi pemasaran untuk dapat memaksimalkan tingkat pertumbuhan dan menguasai pangsa pasar. Masalah dalam perusahaan saat ini adalah penerimaan pendapatan yang masih rendah. Peningkatan pendapatan ini dapat dilakukan jika perusahan lebih ofensif lagi memperluas pasar. Perluasan pasar ditujukan ke pasar tradisional dengan produk Pepaya Jenis California sebagai proyek percontohannya. Analisis data yang digunakan adalah analisis kuantitatif dan kualitatif. Analisis kuantitatif dilakukan untuk mengetahui perilaku pembelian Pepaya California oleh konsumen di Pasar Tradisional. Sedangkan analisis data kualitatif digunakan untuk mengetahui profil pepaya California di pasar. Hasil dari penelitian ini adalah faktor yang mempengaruhi keputusan pembelian Pepaya California di pasar tradisional adalah tingkat kemanisannya, kebersihan kulitnya, dan kesesuaian harganya. Sedang analisis kualitatif dihasilkan informasi bahwa Pepaya California masih langka dan jarang dijumpai di pasar. Strategi bauran pemasaran digunakan untuk menjawab tantangan tersebut. Bagian akhir tesis ini memuat penganggaran biaya dan pencapaian hasil yang diperoleh jika seluruh strategi dapat mencapai target. Dengan membuka pasar bagi produk Pepaya Sunfresh jenis California ini ke pasar tradisional kawasan Jabotabek, ditargetkan penerimaan pendapatan tahunan perusahaan akan naik dan diprediksi meningkat dari 35 milyar rupiah di tahun 2012 menjadi lebih dari 61 milyar rupiah di tahun 2014.
\end{abstract}

Keywords:

Strategi, Pemasaran, Pepaya, California 


\section{PENDAHULUAN}

Indonesia sebagai negara tropis
memiliki potensi besar untuk dapat menghasilkan aneka macam buah sehingga potensi industri yang berkaitan dengan produk buah-buahan pun memiliki peluang yang besar untuk berkembang. Pada tahun 2009, luas area tanaman buah Indonesia sebesar 775.037 Ha dengan produksi 18,34 juta ton dan rata-rata pertumbuhan produksi sebesar $6 \%$. Oleh karenanya, produksi buahbuahan tropis di masa mendatang diperkirakan cenderung meningkat baik dari segi kuantitas maupun kualitasnya. Faktorfaktor yang mempengaruhi adalah meningkatnya tingkat pendapatan per kapita penduduk dunia; meningkatnya jumlah penduduk dunia, dan meningkatnya penguasaan teknologi pengelolaan buah segar.

Kecenderungan masyarakat sampai saat ini, masih lebih menyukai mengkonsumsi buah dalam keadaan segar daripada mengkonsumsi buah olahan. Preferensi perilaku konsumen ini membuka peluang bagi industri yang bergerak di sektor buah segar untuk berkembang karena adanya peningkatan permintaan dari konsumen.

Berdasarkan fenomena di atas, PT Sewu Segar Nusantara (SSN) sebagai perusahaan yang bergerak dalam bidang distribusi dan pemasaran buah segar berskala nasional menangkap peluang tersebut dengan mengembangkan serangkaian strategi pengembangan usaha.

Strategi bisnis SSN Tahun 2011 difokuskan pada usaha peningkatan pendapatan (revenue) sebesar 288 milyar rupiah, meningkat $60 \%$ dari tahun 2010 yaitu sebesar 177 milyar rupiah. Demi mendukung usaha tersebut, SSN menargetkan untuk dapat menekan harga beli buah dari petani (cost of fruits) yang saat ini dirasa masih terlalu tinggi. Cara yang dilakukan adalah dengan membeli langsung ke petani tanpa melalui pengepul dan koordinator sehingga harga beli bisa lebih murah. Cara tersebut bisa dilakukan dengan baik, jika SSN membeli semua hasil panen petani dengan sistem grading. Sebelumnya SSN hanya membeli hasil panen dengan grading kualitas A saja yaitu untuk dijual di pasar modern, namun sekarang SSN akan membeli seluruh hasil panen dengan sistem grading, baik produk dengan kualitas $\mathrm{A}, \mathrm{B}$, maupun $\mathrm{C}$. Strategi ini membutuhkan saluran pemasaran baru untuk bisa menyerap hasil panen dengan kualitas B dan C. Saluran pemasaran baru yang dimaksud adalah pasar tradisional yaitu penjualan melalui grosir dan retail.

Berdasar fakta di atas, SSN berencana untuk menyusun strategi pemasaran yang baru yaitu dengan melakukan market development. Pengembangan pasar akan difokuskan pada beberapa produk buah lokal ke pasar tradisional. Sebagai proyek percontohan, manajemen memutuskan untuk menjalankan proyek peluncuran Pepaya California ke pasar tradisional. Langkah awal yang dilakukan adalah melakukan penelitian mengenai atribut fisik dan pemasaran bagi Pepaya California.

Tujuan dari penelitian tersebut adalah mengetahui apakah terdapat pengaruh antara rasa, warna kulit, kebersihan kulit, kesegaran, kandungan gizi, ukuran, kesesuaian harga, kemasan, promosi, kenyamanan terhadap keputusan pembelian oleh konsumen? serta variabel manakah yang memiliki pengaruh terbesar terhadap keputusan pembelian? Dari penelitian tersebut diperoleh hasil bahwa variabel yang berpengaruh signifikan terhadap keputusan pembelian adalah kebersihan kulit, tingkat rasa, dan kesesuaian harga (Hidayati, 2011).

Hasil penelitian tersebut akan digunakan sebagai dasar dalam melakukan analisis pemasaran Pepaya SUNFRESH jenis 
California Grading B dan C untuk pasar tradisional Kawasan Jabotabek yang selanjutnya digunakan untuk menyusun strategi pemasaran produk tersebut. Produk baru yang akan dianalisis tersebut termasuk kategori New Product Line dimana produk tidak tergolong baru untuk pasar, namun termasuk jenis produk baru bagi perusahaan (Cooper, 1993).

Hasil dari penyusunan strategi tersebut nantinya akan dijadikan pedoman bagi SSN di masa mendatang saat akan mengembangkan dan memasarkan produk ke pasaran khususnya untuk pasar tradisional dengan pembatasan yang disesuaikan dengan jenis produknya.

\section{TINJAUAN PUSTAKA}

\subsection{Agrobisnis Buah Segar}

\subsubsection{Karakteristik Produk Buah Segar}

Buah segar merupakan buah yang dikonsumsi dalam keadaan segar tanpa ada pengolahan atau tanpa pemberian bahan lain (Rahardi, 2000).

\subsubsection{Jenis-Jenis Pasar Buah}

Pasar adalah tempat dimana pembeli dan penjual berkumpul untuk mempertukarkan barang-barang (Kotler,

\subsection{Kualitas Makanan}

Teori ekonomi yang membahas mengenai kualitas produk membahas perbedaan utama antara karakteristik yang berhubungan dengan pencarian, pengalaman dan kepercayaan (Darby dan Karni, 1973). Karakteristik pencarian seperti ukuran, warna, dapat dipastikan sebelum membeli. Sebaliknya, karakteristik pengalaman, misalnya rasa, adalah karakteristik yang hanya dapat diperoleh setelah mengalami produk. Karakteristik kepercayaan berkaitan dengan masalah kredibilitas dan kepercayaan.

Dalam batas tertentu, perbedaan antara pencarian, pengalaman dan karakteristik kepercayaan telah digabungkan ke dalam model multi-atribut dengan cara membedakan antara atribut produk intrinsik dan ekstrinsik (Brunsø et al, 2002.). Faktor intrinsik mengacu pada atribut produk fisik (misalnya rasa, penampilan, kesehatan), sedangkan faktor ekstrinsik mengacu pada segala sesuatu yang lain (misalnya merek, harga, toko, promosi, kemudahan).

\subsection{Decision Making Process \\ Kotler dan Keller}

menjelaskan teori tentang proses pengambilan keputusan sebagai berikut: 2009).

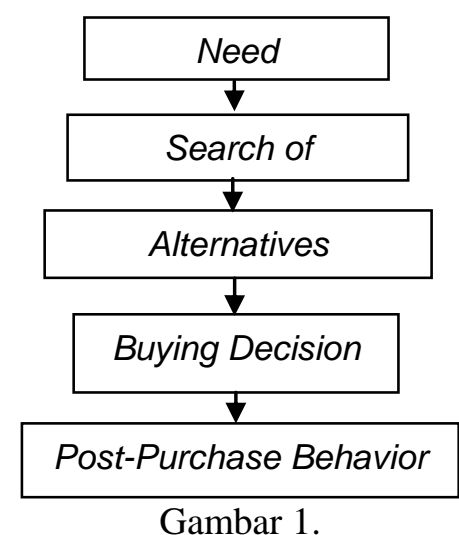

The Five-Stage Model of Consumer Buying Decision Process 
Terdapat lima langkah proses pengambilan keputusan oleh konsumen:

1. Need Recognition

Langkah ini adalah tahap pertama dalam proses pengambilan keputusan ketika konsumen mengenali masalah atau kebutuhan.

2. Search of Information

Tahap kedua proses pengambilan keputusan ketika konsumen sudah memiliki kebutuhan dan didorong untuk mencari informasi lebih lanjut.

3. Evaluation of Alternatives

Evaluasi alternatif adalah ketika konsumen mengevaluasi merek alternatif dari informasi yang tersedia.

4. Buying Decision

Tahap ketika konsumen telah memutuskan produk yang akan dibeli.

5. Post-Purchase Behavior

Setelah menggunakan produk, konsumen akan mengevaluasi apakah produk yang dipilih memenuhi kebutuhan dan harapan mereka.

\subsection{Strategic Marketing Management}

Proses perencanaan pemasaran merupakan perpaduan antara proses berpikir kreatif dan terstruktur (Best, 2009).

\subsection{Analisis Situasi Saat Ini (Current Situation Analysis)}

Analisis situasi saat ini adalah analisis yang didasarkan pada fakta yang ada yang merupakan pra-syarat dalam usaha menyusun rencana pemasaran yang sukses (Best, 2009).

\subsection{Analsis SWOT}

Analisis SWOT merupakan rangkuman kekuatan, kelemahan, peluang, dan ancaman yang belum dibahas dalam analisis situasi (Best, 2009).

\section{7 $\quad$ Formulasi Startegi $\quad$ (Strategic Market Planning) \\ Strategic Market Plan}

dikembangkan berdasarkan informasi yang didapatkan dari hasil analisis situasi dan analisis SWOT (Best, 2009).

\subsection{Segmenting, Targetting, and Positioning}

Segmentasi pasar adalah proses pembagian pasar keseluruhan menjadi kelompok-kelompok pasar yang terdiri dari orang-orang yang secara relatif memiliki kebutuhan produk yang serupa. Targetting atau menetapkan target pasar merupakan tahap selanjutnya dari analisis segmentasi. Positioning adalah menciptakan keunikan posisi produk dalam benak atau persepsi pelanggan potensial yang akan dibidik.

\subsection{Delapan P dalam Strategi Bauran Pemasaran}

Sebagai industri yang menghasilkan sebuah produk fisik sekaligus jasa, SSN menggunakan 8P untuk analisis bauran pemasarannya (Love Lock and Wirtz, 2011) sebagai berikut:

1. Product: barang fisik, jasa, ataupun kombinasi keduanya, yang ditawarkan kepada sasaran.

2. Price: Merupakan sejumlah uang yang harus dikeluarkan konsumen untuk memperoleh produk / jasa hasil perusahaan.

3. Place: Merupakan perencanaan dan pelaksanaan program penyaluran produk melalui lokasi pelayanan yang tepat pada waktu yang tepat dan dengan jumlah yang tepat sesuai dengan kebutuhan konsumen.

4. Promotion:upaya mengkomunikasikan produk dengan para konsumen.

5. Process: Merupakan suatu upaya perusahaan dalam menjalankan dan 
melaksanakan aktivitasnya untuk memenuhi kebutuhan dan keinginan konsumennya secara cepat dan tepat.

6. People: Merupakan orang-orang yang terlibat langsung dalam menjalankan segala aktivitas perusahaan dan merupakan faktor yang memegang peranan penting bagi semua organisasi.

7. Physical evidence: bukti-bukti fisik yang dapat dilihat dan dirasakan oleh alat indra konsumen dapat mencerminkan kualitas dari jasa yang disampaikan kepada konsumen.
8. Productivity: tingkat efisiensi yang bisa dicapai dalam proses penyediaan layanan dari input sampai output, yang bisa menambah nilai bagi pelanggan.

\subsection{Performance Plan}

Perumusan rencana pencapaian kinerja jika seluruh strategi pemasaran tersebut berhasil dijalankan oleh perusahaan.

\subsection{Kerangka Penelitian}

Berikut alur kerangka penelitian pada Gambar 2.

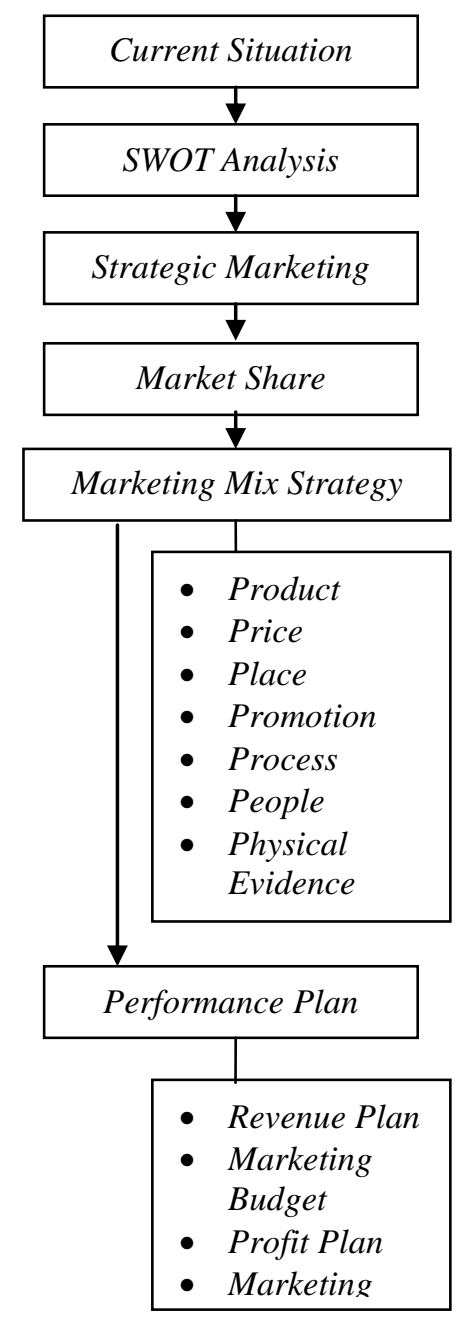

Gambar 2.

Kerangka Analisis 
Langkah pertama dimulai dari analisis terhadap situasi saat ini (current situation analysis) yang memuat analisis atau penilaian mengenai Current performance, market demand, competition \& industry, market share, customer needs, competitive position \& value dari perusahaan (Best, 2009). Langkah selanjutnya adalah dilakukan analisis SWOT yang memuat Strengths, Weaknesses, Opportunities dan Threats dengan tujuan untuk mengidentifikasi isu utama yang mampu meningkatkan kinerja perusahaan.

Dari kedua analisis tersebut akan dihasilkan Strategic Market Plan yang berisi tujuan strategis perusahaan. Analisis ini bertujuan untuk menentukan tujuan kinerja dan rencana pemasaran yang spesifik selama satu periode dengan memperhatikan aspek investasi yang dikeluarkan serta tujuan peningkatan market share yang diinginkan perusahaan (market share objectives). Analisis dilakukan dengan menggunakan analisis portfolio perusahaan. Dari hasil analisis portfolio tersebut dirumuskan strategi pemasaran yang memfokuskan pada perumusan STP (Segmenting, Targetting, dan Positioning) dengan menurunkannya menjadi implementasi strategi berupa Marketing Mix Strategy yang memuat 8P dalam pemasaran yaitu aspek product, price, place, promotion, people, process, physcial evidence, dan productivity.

Setelah dirumuskan strategi bauran pemasaran tersebut perlu dirumuskan rencana kinerja (performance plan) yang memuat pembahasan mengenai Revenue plan, marketing budget, profit plan, dan performance scorecard.

\section{METODE PENELITIAN}

\subsection{Metode Pengumpulan Data}

Metode pengumpulan data yang digunakan adalah sebagai berikut:
1. Observasi

Observasi dilakukan dengan mengamati proses bisnis perusahaan terutama bagian sourcing, sales dan product supply perusahaan dan mengamati proses jual beli yang dilakukan oleh penjual grosir dan retail di beberapa pasar tradisional di kawasan Jabotabek.

2. Wawancara

Wawancara ini dilakukan secara terstruktur dengan metode depth interview kepada beberapa pihak, baik internal maupun eksternal perusahan. Sumber untuk wawancara internal antara lain direktur sales dan marketing, manajer sourcing, manajer accounting, dan manager PSO (Product Supply Organization), karyawan sales pasar, masing-masing 1 orang. Sedangkan untuk narasumber eksternal, wawancara dilakukan kepada pemilik grosir retail pasar tradisional di Kawasan Jabotabek, masing-masing sebanyak 2 orang.

3. Kuosioner

Riset "Faktor-Faktor yang Mempengaruhi Keputusan Pembelian Pepaya California oleh Konsumen di pasar Tradisional di Kawasan Jabotabek TM" dengan jumlah responden sebanyak 240 orang. Penelitian telah dilakukan saat Kerja Praktek Bulan Maret 2011.

Responden adalah konsumen sekaligus pembeli Pepaya California yang membeli di Pasar Tradisional pada kurun waktu 6 bulan terakhir. Pengumpulan data dilakukan dengan menggunakan kuesioner.

4. Literature Review

Melakukan peninjauan terhadap data internal dan eksternal. Data internal meliputi daftar grosir dan retailer serta data penjualan. Sedangkan data eksternal meliputi literatur, buku-buku, koran, majalah, internet, jurnal, serta hasil-hasil 
riset lainnya yang terkait dengan penelitian.

\subsection{Metode Analisis Data}

Metode analisis data yang digunakan dalam penulisan tesis ini sebagai berikut:

1. Analisis Data Kuantitatif

Analisis data kuantitatif dilakukan dengan statistika parametrik dengan menggunakan aplikasi SPSS 9.0 untuk menganalisis faktor-faktor yang mempengaruhi keputusan pembelian Pepaya California oleh konsumen di pasar tradisional di Kawasan Jabotabek.
2. Analisis Data Kualitatif

Dilakukan dengan mengidentifikasi data yang berhasil dikumpulkan dari proses wawancara baik dengan pihak internal maupun eksternal perusahaan.

\section{ANALISIS}

\subsection{Analisis Situasi Saat Ini \\ 4.1.1 Current Performance a. Sales and NIBT} Gambar 3

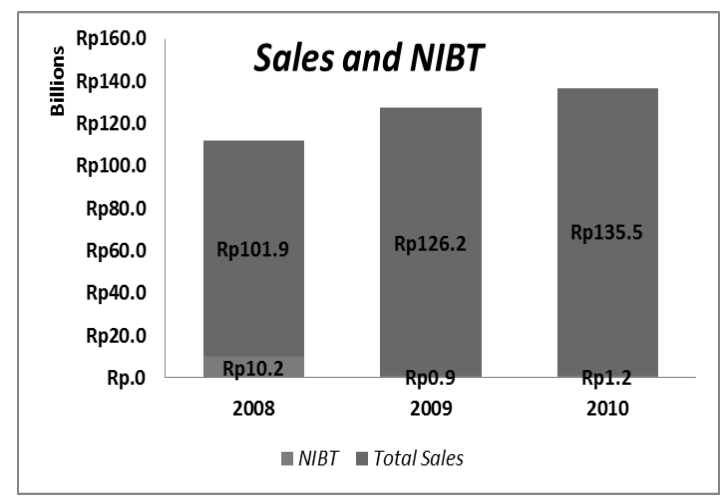

Gambar 3.

Sales Revenue and NIBT

Dari Gambar 3. dapat dilihat bahwa SSN mencapai NIBT terbesar pada tahun 2008 yaitu sebesar 10,2 milyar rupiah $(10 \%$ dari sales) lalu mengalami penurunan tajam pada tahun 2009 hingga mengalami kerugian dengan NIBT hanya 0,9 milyar rupiah $(0,7 \%$ dari sales), dan tahun 2010 dapat mencapai titik impas dengan NIBT sebesar 1,2 milyar rupiah $(0,9 \%$ dari sales). Hanya pada tahun 2008, SSN mampu mencapai standar prosentase NIBT yang ditetapkan oleh perusahaan yaitu sebesar $10 \%$ dari sales.

\section{b. Penjualan di Pasar Tradisional}

Gambar 4. menjelaskan bahwa penjualan SSN didominasi oleh penjualan di pasar modern dengan penjualan per bulan berkisar antara 4-7 milyar rupiah dengan persentase sebesar 55\%. Penjualan terbesar kedua berada di pasar tradisional, sedangkan sisanya adalah penjualan secara individu dalam bentuk sub distributor yang tidak termasuk kategori keduanya. 


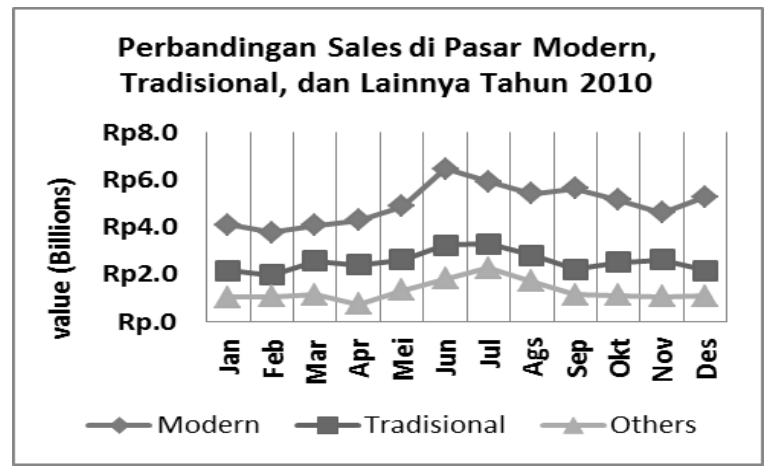

Gambar 4.

Sales di Pasar Tradisional, Modern, dan Lainnya

\section{c. Marketing Performance Metrics}

Tabel 1. menjelaskan bahwa penjualan SSN terus meningkat dengan tingkat pertumbuhan $20 \%$ per tahun seiring dengan rata-rata pertumbuhan pasar dan pertumbuhan share. Hasil penghitungan dari marketing profits sebesar $16 \%$ dan marketing ROI sebesar $348 \%$.

Tabel 1.

Marketing Performance Metrics

\begin{tabular}{|c|c|}
\hline Performance & 2010 \\
\hline Market Demand & 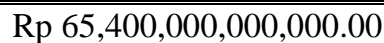 \\
\hline Market Share & $26.67 \%$ \\
\hline Sales Revenues & Rp 177,000,000,000.00 \\
\hline Percent Margin & $20.00 \%$ \\
\hline Gross Profit & Rp 35,400,000,000.00 \\
\hline Marketing, Sales, Adm & Rp 7,910,106,110.00 \\
\hline Net Marketing Contribution & Rp 27,489,893,890.00 \\
\hline Marketing ROS & $16.00 \%$ \\
\hline Marketing ROI & $348.00 \%$ \\
\hline
\end{tabular}

\subsubsection{Market Demand}

\section{a. Pasar Potensial Buah Segar}

Tabel 2. menjelaskan bahwa daerah cakupan untuk penghitungan pasar potensial adalah Jabotabek mengingat daerah penjualan yang akan dimaksimalkan pasarnya adalah daerah tersebut. Strategi pengembangan pasar dapat dilakukan dengan memberikan manfaat tambahan pada produk ataupun pengurangan harga. Dengan harga rata-rata buah Rp. 8.000/kg (Hidayati, 2011), penjualan retail per tahun mampu mencapai Rp. 6,7 Trilyun jika seluruh konsumen potensial mampu distimulus untuk memasuki pasar. 
Tabel 2.

Perkiraan Pasar Potensial Buah Segar

\begin{tabular}{||l|r|}
\hline \hline Geographic scope of market focus & Jabotabek \\
\hline \hline Scale & None \\
\hline \hline Consuming unit & Individual $(\mathrm{Kg})$ \\
\hline \hline Current Market Demand $(\mathrm{kg})$ & $470,423,573$ \\
\hline \multicolumn{1}{|c|}{ Performance factors } & Performance \\
\hline \hline Max. number of consuming units & $30 \%$ \\
\hline \hline Annual Purchase rate & 33 \\
\hline \hline Quantity purchase rate & $846,762,432$ \\
\hline \hline Market Potential (units) & $55.6 \%$ \\
\hline \hline Market Development Index $($ MDI) & $\mathrm{Rp} 8,000.00$ \\
\hline \hline Average Price & $6,74,099,456,960.00$ \\
\hline \hline Market Potential(Rupiahs) & \\
\hline
\end{tabular}

Assumption :Market Demand per year

Number of population Jabotabek : 14,386,042

\section{b. Pasar Potensial Pepaya California}

Hasil penghitungan skor MDI adalah $11,5 \%$ yang diperoleh dengan cara membandingkan current market demand dengan market potential. Angka tersebut menunjukkan bahwa pertumbuhan pasar potensial masih sangat besar. Dengan harga rata-rata buah Rp. $8.000 / \mathrm{kg}$, dimungkinkan penjualan retail per tahun mampu mencapai Rp.250 milyar (Tabel 3.) jika seluruh konsumen potensial berhasil distimulus untuk memasuki pasar.

Tabel 3.

Perkiraan Pasar Potensial Pepaya California

\begin{tabular}{||l|r|}
\hline Geographic scope of market focus & Jabotabek \\
\hline \hline Scale & None \\
\hline \hline Consuming unit & Individual $(\mathrm{Kg})$ \\
\hline \hline Current Market Demand $(\mathrm{kg})$ & $3,600,000$ \\
\hline \hline \multicolumn{1}{|c|}{ Performance factors } & Performance \\
\hline \hline Max. number of consuming units & $9,590,694.67$ \\
\hline \hline Annual Purchase rate & $30 \%$ \\
\hline \hline Quantity purchase rate & 2 \\
\hline \hline Market Potential $($ units) & $31,361,571.56$ \\
\hline \hline Market Development Index $($ MDI) & $11.5 \%$ \\
\hline \hline Average Price & $\mathrm{Rp} 8,000.00$ \\
\hline \hline Market Potential (Rupiahs) & $250,892,572,480.00$ \\
\hline \hline
\end{tabular}

Assumption

Market Demand Papaya per days

100 ton

Share of California Papaya

$10 \%$ 


\subsubsection{Competitor and Industry}

Berikut adalah hasil analisis ketertarikan industri (Tabel 4.)

Tabel 4.

Analisis Ketertarikan Industri

\begin{tabular}{||l||c||c|c||}
\hline $\begin{array}{c}\text { Industry } \\
\text { Forces }\end{array}$ & $\begin{array}{c}\text { Relative } \\
\text { Importance }\end{array}$ & $\begin{array}{c}\text { Grosir (Large } \\
\text { Quantity) }\end{array}$ & $\begin{array}{c}\text { Retailer (Small } \\
\text { Quantity) }\end{array}$ \\
\hline \hline Compt. entry & $15 \%$ & 65 & 50 \\
\hline \hline Compt. exit & $10 \%$ & 65 & 50 \\
\hline \hline Substitutes & $10 \%$ & 60 & 65 \\
\hline Buyer Power & $30 \%$ & 50 & 40 \\
\hline \hline Seller Power & $5 \%$ & 50 & 40 \\
\hline \hline Price Rivalry & $30 \%$ & 30 & 20 \\
\hline & $100 \%$ & 48.75 & 39 \\
\hline
\end{tabular}

Dari Tabel 4. di atas dapat disimpulkan jika daya tarik industri buah segar kurang menarik dikarenakan persaingan harga yang tinggi dan daya tawar penjual yang rendah. Namun segmen grosir lebih menarik dibanding segmen retail sehingga lebih berpotensi menghasilkan keuntungan.

\subsection{Analisis SWOT}

\subsubsection{Strengths (Kekuatan)}

Kekuatan perusahaan adalah sebagai berikut :

- Memiliki reputasi sebagai perusahaan dengan kualitas produk yang superior khususnya Cavendish dan buah lokal.

- Menjalin hubungan yang baik dengan pelanggan dan konsumen.

- Mampu mengirimkan produk dengan pola harian dan rutin.

- Mudah menambah jumlah outlet karena popularitas pisang Sunpride yang banyak diminati pelanggan.

- Memiliki fokus utama pada pengembangan brand dimana tidak banyak industri buah segar yang mengembangkan brand nya.

\subsubsection{Weakness (Kelemahan)}

Kelemahan perusahaan adalah sebagai berikut:

- Profitabilitas keuangan yang rendah (NIBT 2010: 0,67\% dari revenue).

- Account Receivable days (Waktu pengembalian piutang oleh pelanggan) yang tinggi.

- Biaya operasional yang tinggi.

- Kurang konsisten dalam penyediaan jumlah produk maupun variasinya.

- Kurang tanggap dalam merespon kondisi pasar terutama yang berhubungan dengan penentuan harga.

\subsubsection{Opportunities (Tantangan)}

Tantangan perusahaan adalah sebagai berikut:

- Tingginya permintaan produk buah segar (Tahun 2010: 925 juta kg/ tahun).

- Pasar industri buah segar Indonesia belum didomimasi oleh satu brand.

- Pertambahan jumlah pendapatan per kapita.

- Pemenuhan standar FAO tentang kebutuhan minimal konsumsi buah per kapita per tahun yaitu $73 \mathrm{~kg}$. 
- Pertumbuhan pasar ritel modern (minimarket) sangat tinggi yaitu $42 \%$ tahun 2010 (Nielsen, 2010).

\subsubsection{Threats (Ancaman)}

Ancaman perusahaan di bidang sales adalah sebagai berikut :

- Segar sebagian besar adalah perusahaan dengan biaya operasional yang relatif rendah.

- Kondisi alam yang sukar diprediksi sehingga mempengaruhi kontinuitas dan kuantitas suplai produk lokal.

- Kondisi infrastruktur Indonesia yang kurang berkembang sehingga menghambat pengembangan pasar.

Ancaman perusahaan di bidang procurement adalah sebagai berikut:

- Kurangnya pengetahuan petani lokal dalam peningkatan kualitas buah.

- Kurang terampilnya kemampuan petani lokal dalam menghasilkan buah berkualitas.

- Rendahnya loyalitas pelanggan (grosir).

- Rendahnya loyalitas supplier pemasok.

\section{FORMULASI STRATEGIS \\ PEMASARAN}

\subsection{Daya Tarik Pasar}

Terdapat 3 dimensi yang menentukan sebuah industri dikatakan menarik atau tidak yaitu dukungan pasar (market forces), situasi persaingan (competitive environment), dan akses pasar (market access). Dalam industri distributor buah segar, dimensi yang paling mempengaruhi kinerja pasar adalah situasi persaingan $(50 \%)$, dukungan pasar $(33 \%)$, dan akses pasar (17\%). Penentuan tersebut adalah hasil pembobotan menggunakan pairwise comparison. Kemudian dari setiap dimensi ditentukan faktor-faktor pembentuknya dan dilakukan pembobotannya berdasarkan derajad kepentingannya. Hasil skor daya tarik pasar adalah 52,95 yang berarti pasar cukup menarik (average) seperti dapat terlihat pada Tabel 5. berikut.

Tabel 5.

Daya Tarik Pasar

\begin{tabular}{|c|c|c|c|}
\hline Market Forces (33\%) & Rel Imp & Attractive rating & Attractive rating \\
\hline Market size & $50 \%$ & 80 & 40 \\
\hline Growth rate & $33 \%$ & 80 & 14 \\
\hline \multirow[t]{2}{*}{ Buyer power } & $17 \%$ & 40 & 7 \\
\hline & $100 \%$ & & 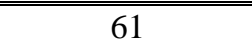 \\
\hline Competitive env. (50\%) & Rel Imp & Attractive rating & Attractive rating \\
\hline Price rivalry & $50 \%$ & 40 & 20 \\
\hline Ease of comp. entry & $17 \%$ & 60 & 10 \\
\hline \multirow[t]{2}{*}{ No of competitor } & $33 \%$ & 60 & 20 \\
\hline & $100 \%$ & & 50 \\
\hline Market access (17\%) & Rel Imp & Attractive rating & Attractive rating \\
\hline Customer familiarity & $50 \%$ & 40 & 20 \\
\hline Channel access & $33 \%$ & 60 & 20 \\
\hline \multirow[t]{2}{*}{ Sales requirements } & $17 \%$ & 40 & 7 \\
\hline & $100 \%$ & & 47 \\
\hline
\end{tabular}




\begin{tabular}{||l||c||c||}
\hline Market attract. index & 20.02 & \multirow{1}{*}{} \\
\cline { 2 - 2 } & 25.00 & \\
\cline { 2 - 2 } & 7.93 & \\
\cline { 2 - 3 } & $\mathbf{5 2 . 9 5}$ & \\
\hline
\end{tabular}

5.2 Kemampuan Bersaing Perusahaan

Daya saing SSN sebagai perusahaan distribusi buah segar ditinjau dari keunggulan diferensiasi, keunggulan harga, dan keunggulan pemasaran. Keunggulan diferensiasi diberi bobot paling tinggi (50\%), lalu diikuti keunggulan harga (33\%), selanjutnya keunggulan pemasaran (17\%). Hasil skor kemampuan bersaing adalah 70,13 yang artinya SSN sangat kuat dalam bersaing dengan memanfaatkan keunggulan bersaing yang dimiliki. Berikut penilaian index daya saing perusahaan pada Tabel 6 .

Tabel 6.

Kemampuan Bersaing Perusahaan

\begin{tabular}{|c|c|c|c|}
\hline $\begin{array}{c}\text { Differentiation advantage } \\
(50 \%)\end{array}$ & Rel Imp & Attractive rating & Attractive rating \\
\hline Product quality & $50 \%$ & 100 & 50 \\
\hline Service quality & $33 \%$ & 80 & 26 \\
\hline \multirow[t]{2}{*}{ Brand image } & $17 \%$ & 80 & 14 \\
\hline & $100 \%$ & & 90 \\
\hline Cost advantage (33\%) & Rel Imp & Attractive rating & Attractive rating \\
\hline COGS & $67 \%$ & 20 & 13 \\
\hline Marketing expense & $16 \%$ & 80 & 13 \\
\hline \multirow[t]{2}{*}{ Overhead expense } & $17 \%$ & 60 & 10 \\
\hline & $100 \%$ & & 37 \\
\hline Marketing advantage (17\%) & Rel Imp & Attractive rating & Attractive rating \\
\hline Market share & $50 \%$ & 60 & 30 \\
\hline Brand awareness & $17 \%$ & 80 & 13 \\
\hline \multirow[t]{2}{*}{ Distribution } & $33 \%$ & 100 & 33 \\
\hline & $100 \%$ & & 77 \\
\hline \multirow[t]{4}{*}{ Competitive Positioning Index } & 45.00 & & \\
\hline & 12.10 & & \\
\hline & 13.03 & & \\
\hline & 70.13 & & \\
\hline
\end{tabular}

\subsection{Portfolio Strategic}

Perusahaan SSN ditinjau dari daya tarik pasar dan kemampuan bersaing. Skor daya tarik pasar sebesar 52,95 yang berarti pasar cukup menarik (average), dan skor kemampuan bersaing sebesar 70,13 yang artinya SSN sangat kuat dalam bersaing dengan memanfaatkan keunggulan bersaing yang dimiliki.
Dari koordinat kedua skor tersebut dapat diketahui posisi SSN secara industri dan internal. SSN berada di posisi tengah sebelah kanan yaitu sangat baik dalam merespon tantangan industri dengan memanfaatkan kekuatan internal yang dimiliki. Posisi ini menentukan strategi apa yang sebaiknya diambil perusahaan yaitu strategi Offensive. 


\subsection{Strategi Offensive Terpilih}

Beberapa produk lokal SSN pun perlu ditingkatkan seperti pepaya California yang saat ini sangat diminati di masyarakat karena kualitasnya yang superior dibanding pepaya bangkok. Strategi tersebut termasuk strategi perluasan segmen pasar ke pasar tradisional.

\subsection{Daya Tarik Pasar Pepaya California}

Skor daya tarik industri Pepaya California di pasar tradisional adalah 54,69 yang artinya pasar cukup menarik untuk dimasuki (Tabel 7.).

Tabel 7.

Daya Tarik Pasar Pepaya California

\begin{tabular}{|c|c|c|c|}
\hline Market Forces (33\%) & Rel Imp & Attractive rating & Attractive rating \\
\hline Market size & $50 \%$ & 80 & 40 \\
\hline Growth rate & $33 \%$ & 80 & 14 \\
\hline \multirow[t]{2}{*}{ Buyer power } & $17 \%$ & 40 & 7 \\
\hline & $100 \%$ & & 261 \\
\hline $\begin{array}{c}\text { Competitive environment } \\
(50 \%)\end{array}$ & Rel Imp & Attractive rating & Attractive rating \\
\hline Price rivalry & $50 \%$ & 40 & 20 \\
\hline Ease of comp. entry & $17 \%$ & 40 & 7 \\
\hline \multirow[t]{2}{*}{ No of competitor } & $33 \%$ & 60 & 20 \\
\hline & $100 \%$ & & 47 \\
\hline Market access (17\%) & Rel Imp & Attractive rating & Attractive rating \\
\hline Customer familiarity & $50 \%$ & 60 & 30 \\
\hline Channel access & $33 \%$ & 80 & 27 \\
\hline \multirow[t]{2}{*}{ Sales requirements } & $17 \%$ & 60 & 10 \\
\hline & $100 \%$ & & 67 \\
\hline \multirow[t]{4}{*}{ Market attractiveness Index } & 20.02 & & \\
\hline & 23.33 & & \\
\hline & 11.33 & & \\
\hline & 54.69 & & \\
\hline
\end{tabular}

\subsection{Kemampuan Bersaing Pepaya Sunfresh California}

Skor kemampuan bersaing Pepaya Sunfresh California adalah 26,13 yang artinya kurang mampu bersaing, seperti terlihat pada Tabel 8 . berikut.

Tabel 8.

Kemampuan Bersaing Pepaya Sunfresh California

\begin{tabular}{||c|c||c|c||}
\hline $\begin{array}{c}\text { Differentiation advantage } \\
(\mathbf{5 0 \%})\end{array}$ & Rel Imp & Attractive rating & Attractive rating \\
\hline Product quality & $50 \%$ & 40 & 20 \\
\hline \hline Service quality & $33 \%$ & 20 & 7 \\
\hline Brand image & $17 \%$ & 20 & 30 \\
\hline & $100 \%$ & & 30 \\
\hline
\end{tabular}




\begin{tabular}{|c|c|c|c|}
\hline Cost advantage (33\%) & Rel Imp & Attractive rating & Attractive rating \\
\hline COGS & $67 \%$ & 20 & 14 \\
\hline Marketing expense & $16 \%$ & 20 & 3 \\
\hline \multirow[t]{2}{*}{ Overhead expense } & $17 \%$ & 20 & 3 \\
\hline & $100 \%$ & & 20 \\
\hline Marketing advantage (17\%) & Rel Imp & Attractive rating & Attractive rating \\
\hline Market share & $50 \%$ & 20 & 10 \\
\hline Brand awareness & $17 \%$ & 20 & 3 \\
\hline \multirow[t]{2}{*}{ Distribution } & $33 \%$ & 40 & 13 \\
\hline & $100 \%$ & & 27 \\
\hline \multirow[t]{4}{*}{ Competitive Positioning Index } & 15.00 & & \\
\hline & 6.60 & & \\
\hline & 4.53 & & \\
\hline & 26.13 & & \\
\hline
\end{tabular}

\subsection{Portfolio Strategic}

Dari koordinat kedua skor tersebut kita akan tahu dimana letak Pepaya Sunfresh jenis California SSN secara industri dan internal. Pepaya Sunfresh jenis California berada di posisi tengah sebelah kiri yaitu belum mampu merespon tantangan industri karena kekuatan internal yang masih belum siap. Posisi ini menentukan strategi apa yang sebaiknya diambil perusahaan yaitu strategi Offensive.

\subsection{Strategi Offensive Terpilih}

Strategi yang dipilih untuk Pepaya Sunfresh adalah dengan mengembangkan daerah pemasaran baru (develop new market). Pengembangan pasar baru adalah pilihan strategi untuk mengembangkan pasar produk pepaya California Sunfresh. Pasar yang baru yang dimaksud adalah pasar tradisional yang ada di kawasan Jabotabek.

\subsection{Market Share Objectives}

Market share tahun 2012 diawali dengan $8 \%$, per tahunnya market share diharapkan meningkat lebih dari 20\%, sehingga pada tahun 2014 market Share Pepaya Sunfresh akan mencapai 11,6\%. Dengan keberhasilan peningkatan marketing performance metrics akan meningkatkan share index dan meningkatkan share masingmasing sebesar $11,6 \%$ dari $8 \%$ dalam waktu tiga tahun proyek berjalan (Tabel 9.)

Tabel 9.

Market Share Objectives

\begin{tabular}{|c||c||c|c|}
\hline Share Metrics & $\mathbf{2 0 1 2}$ & $\mathbf{2 0 1 3}$ & $\mathbf{2 0 1 4}$ \\
\hline \hline Served Market & $50 \%$ & $55 \%$ & $57 \%$ \\
\hline \hline Awareness & $55 \%$ & $58 \%$ & $59 \%$ \\
\hline \hline Consideration & $60 \%$ & $62 \%$ & $65 \%$ \\
\hline \hline Preference & $65 \%$ & $67 \%$ & $68 \%$ \\
\hline \hline Purchase & $75 \%$ & $77 \%$ & $78 \%$ \\
\hline \hline Share index & $\mathbf{8 . 0 \%}$ & $\mathbf{1 0 . 2 \%}$ & $\mathbf{1 1 . 6 \%}$ \\
\hline
\end{tabular}


VI. STRATEGI PEMASARAN

\subsection{Segmentasi dan Targetting}

Dari hasil segmentasi menggunakan

Cross tabulation didapatkan 2 target konsumen berikut segmentasinya. Segmentasi konsumen Pepaya Sunfresh Jenis California dibedakan berdasarkan demografis konsumen sebagai berikut (Tabel 10.):

Tabel 10.

Segmentasi Konsumen Pepaya Sunfresh berdasarkan Demografis (Hasil Cross Tabulation)

\begin{tabular}{||c||c|c|c|c||}
\hline Atribut & $\begin{array}{c}\text { Segmen A } \\
\text { (executives) }\end{array}$ & $\begin{array}{c}\text { Segmen B } \\
\text { (Working wives) }\end{array}$ & $\begin{array}{c}\text { Segmen C } \\
\text { (Housewives) }\end{array}$ & $\begin{array}{c}\text { Segmen D (Retired } \\
\text { woman) }\end{array}$ \\
\hline $\begin{array}{c}\text { Pengeluaran rata- } \\
\text { rata }\end{array}$ & $\begin{array}{c}\text { Lebih dari Rp } \\
3.000 .000,00\end{array}$ & $\begin{array}{c}\text { Rp 2.000.000,00- } \\
\mathrm{Rp} 3.000 .000,00\end{array}$ & $\begin{array}{c}\mathrm{Rp} 1.500 .000,00- \\
\mathrm{Rp} 2.000 .000,00\end{array}$ & $\begin{array}{c}\text { Rp 700.000,00- } \\
\mathrm{Rp} \mathrm{1.000.000,00}\end{array}$ \\
\hline \hline Sosial ekonomi & $\mathrm{A}$ & $\mathrm{B}$ & $\mathrm{C}$ & $\mathrm{C}-$ \\
\hline $\begin{array}{c}\text { Frekuensi } \\
\text { pembelian }\end{array}$ & Sebulan sekali & Seminggu sekali & $2-3$ hari sekali & Dua minggu \\
\hline \hline Informasi & Penjual & Teman & Keluarga & Rekan \\
\hline \hline Usia responden & $21-30$ tahun & $31-40$ tahun & $41-50$ tahun & 51-60 tahun \\
\hline \hline Pendidikan & $\mathrm{S} 1$ & $\mathrm{D} 3$ & SMA & SMA \\
\hline
\end{tabular}

\subsection{Positioning}

Berdasarkan proses segmentasi dan targetting di atas, maka diperoleh analisis positioning untuk Pepaya California Milik SSN di Pasar Tradisional adalah "Pepaya kualitas superior dengan rasa yang konsisten manis, kulit yang bersih dan harga terjangkau untuk konsumen pasar tradisional".

\subsection{Strategi 8P Bauran Pemasaran 6.3.1 Strategi Produk}

Strategi produk memuat di dalamnya mengenai spesfifikasi produk Pepaya Sunfresh yang akan dipasarkan ke pelanggan. Berikut adalah spesifikasi yang dimaksud (Tabel 11.):

Tabel 11.

Spesifikasi Pepaya Sunfresh California

\begin{tabular}{||l||c||c|}
\hline \multicolumn{1}{|c||}{ Uraian } & Spesifikasi Grade B & Spesifikasi Grade C \\
\hline \hline Ukuran & Kecil - sedang & Besar - sedang \\
\hline \hline Kekotoran kulit & $10 \%-20 \%$ & $20 \%-30 \%$ \\
\hline \hline Bentuk & Proporsional & Malform $10 \%$ \\
\hline \hline Kematangan & $90 \%$ (3 polet) & $90 \%-95 \%$ (3 - 4 polet) \\
\hline \hline Penampakan kulit & $\begin{array}{c}\text { Warna kulit semu kuning merata } \\
\text { di seluruh badan }\end{array}$ & $\begin{array}{c}\text { Warna kulit semu kuning merata } \\
\text { di seluruh badan }\end{array}$ \\
\hline \hline Kemasan & Krat & Krat \\
\hline \hline Berat kemasan & $18 \mathrm{~kg}$ & $18 \mathrm{~kg}$ \\
\hline \hline
\end{tabular}

\subsubsection{Strategi Harga}

Harga Pepaya Sunfresh ditetapkan relatif lebih tinggi dibanding pesaing yaitu
Rp. 7.500 untuk segmen retail dan Rp. 7.000 untuk segmen grosir untuk per kilogram seperti terlihat pada Tabel 12. berikut. 
Tabel 12.

Harga Tingkat Retail dan Grosir

\begin{tabular}{|c||c|c|c|c||c|c|c|}
\hline Berat / box & Isi / box & Ukuran & Satuan jual & Retailer (Price B) & \multicolumn{2}{|c|}{ Grosir ( Price C) } \\
\hline \hline & & & & Box & $(\mathrm{kg} / \mathrm{pc} / \mathrm{ssr})$ & box & $(\mathrm{kg} / \mathrm{pc} / \mathrm{ssr})$ \\
\hline \hline 18 & $9-15$ & krat & $\mathrm{kg}$ & 135.000 & 7.500 & 126.000 & 7000 \\
\hline
\end{tabular}

Meski harga tersebut relatif lebih tinggi dari pesaing, namun tidak akan menurunkan loyalitas pelanggan karena PT SSN berkomitmen untuk selalu mengutamakan pelayanan kepada pelanggan dengan cara tidak hanya membantu pelanggan dalam pendistribusian hingga sampai ke tempat tujuan tetapi juga membantu pelanggan sampai ke tingkat konsumen akhir seperti membantu pelanggan dalam display buah atau membantu menjual buah ke konsumen akhir. Selain itu, adanya bonus buah yang diberikan kepada pelanggan pada saat harga buah pepaya di pasaran rendah karena pasokan yang terlalu melimpah patut dipertahankan, karena hal itu akan menarik minat pelanggan untuk membeli buah dengan jumlah banyak.

\subsubsection{Strategi Promosi}

Strategi advertising below the line yaitu melalui penjual secara langsung dengan cara mengedukasi penjual mengenai kelebihan Pepaya California milik SSN. Pemberian merek juga diperlukan saat melakukan transaksi antara grosir dan retail juga pembeli. Untuk segmen grosir strategi rekognisi bisa disampaikan dengan T-shirts, atau promosi taktis untuk menghabiskan stok buah lain seperti "Membeli Pisang Cavendish 1 box" gratis $10 \mathrm{~kg}$ Pepaya Sunfresh". Strategi ini berguna untuk stock clearing sekaligus strategi trial promo.

Untuk Toko buah (retail) diperlukan strategi In store visibility yaitu dengan mobile hanger, banner, poster ataupun shelf strip yang didalamnya memuat produkproduk baru yang siap diluncurkan ke pasar tradisional termasuk Pepaya Sunfresh
California, semua dengan mengusung merek SUNFRESH. Strategi branding sekaligus promosi juga dapat dilakukan dengan pemberian seragam bagi staf penjual di toko berlabel Sunpride dan Sunfresh sekaligus sehingga brand awareness keduanya juga akan terbangun.

Strategi branding juga dilakukan dengan mengkomunikasikan benefit mengkonsumsi Pepaya Sunfresh California yaitu memperlancar pencernaan, mengandung banyak vitamin $\mathrm{C}$, dan mengeluarkan racun tubuh. Value benefit ini perlu disampaikan kepada calon pelanggan dan konsumen dalam bentuk edukasi langsung melalui penjual sehingga mereka memutuskan untuk membeli Pepaya Sunfresh California.

\subsubsection{Strategi Lokasi dan Distribusi}

Daerah pemasaran Pepaya California telah sesuai jika difokuskan di Kawasan Jabotabek dengan pilihan pasar tradisional yang berada di lingkungan masyarakat yang termasuk kelompok sosial ekonomi A, B, dan C. Hal ini dikarenakan daya beli masyarakat golongan tersebut cukup tinggi untuk Pepaya California (Hidayati, 2011) mengingat harga yang akan dipatok PT SSN untuk Pepaya Sunfresh cukup tinggi namun dengan jaminan kualitas produk yang lebih baik dibanding pesaing. Pepaya Sunfresh Grade B akan dipasarkan di toko buah semi permanen di pinggir jalan dan pasar tradisonal semi modern seperti Pasar-pasar tradisional di lingkungan Jaya Properti seperti BSD, Alam Sutra, atau Pasar Anyar Tangerang, dimana lingkungannya di 
kelilingi golongan sosial eknonomi menengah ke atas.

Sedangkan Grade C akan dipasarkan di grosir pasar Induk seperti Kramat Jati Jakarta Timur. Salah satu faktor yang mendukung kelancaran rantai pasokan adalah saluran distribusi. PT SSN harus menjamin kontinuitas dan kuantitas pepaya sesuai dengan permintaan pelanggan. Cara yang dilakukan adalah mencari dan menjalin kerjasama yang baik dengan sumber-sumber pemasok yang baru dengan tetap memperhatikan kualitas produk dan harga beli buah yang mampu bersaing.

Strategi lokasi dan distribusi lain yang dapat dilakukan adalah dengan meletakkan grosir resmi SSN di pasar induk dengan tingkat pembelian paling potensial di Jakarta seperti pasar induk Kramat jati. Strategi ini sedang dilakukan oleh SSN dengan tujuan untuk memberikan contoh bagaimana menjual produk SSN, sekaligus sebagai kontrol atau pengawasan terhadap grosir atau retail di pasar tradisional yang menjual produk SSN di pasar tersebut. Hal ini dilakukan untuk menghindari kemungkinan terjadinya kecurangan penentuan harga oleh pelanggan di pasar induk tersebut. Tujuan lainnya adalah sebagai wakil SSN, grosir ini akan dijadikan grosir percontohan sehingga akan banyak lagi jumlah calon pelanggan yang ingin bekerjasama. Grosir percontohan ini akan mempraktekkan bagaimana berjualan, penetapan harga yang baik, serta bagaimana menangani keluhan pelanggan dengan cara yang baik pula.

\subsubsection{Strategi terkait dengan Personel}

Untuk memasarkan Pepaya Sunfresh jenis California ini membutuhkan peran sales pasar yang kompeten. Jumlah tenaga penjual untuk pasar tradisional sekarang ini berjumlah 4 orang. Jumlah ini sudah cukup baik untuk meningkatkan penjualan.
Kelemahan sales saat ini adalah kurangnya pemahaman akan produk yang ditawarkan terkait keunggulan dan benefit yang akan diperoleh calon konsumen. Sales juga kurang tanggap dalam merespon keluhan pelanggan sehingga untuk selanjutnya diperlukan training mengenai teknik menjual dan product knowledge yang saat ini belum pernah dilakukan untuk sales pasar tradisional.

\subsubsection{Strategi terkain Proses Pemasaran}

Strategi sourcing, produksi, dan distribusi untuk Pepaya Sunfresh relatif sama dengan produk lain yang telah ada di PT SSN. Namun keunikannya adalah pada saat sourcing dilakukan, perlu diperhatikan pengelompokan spesifikasi kelas sehingga dari hulu hingga hilir spesifikasi ini tidak berubah yang nantinya akan mempengaruhi penetapan harga produk tersebut di pasaran.

\subsubsection{Strategi terkait Atribut Fisik Pendukung}

Untuk memberikan atmosfer dan penanda bahwa produk yang dijual oleh pelanggan adalah produk SSN, atribut yang dipergunakan adalah seragam yang digunakan oleh sales setiap kali berkunjung ataupun saat menawarkan produk ke calon pelanggan. Bonus berupa kaos dengan logo Sunfresh California Papaya juga dapat diberikan kepada pelanggan dengan jumlah pembelian minimal 50 krat misalnya.

\subsubsection{Strategi terkait Produkitivitas Penjualan \\ Produktivitas yang dimaksud adalah} kinerja staf penjualan dalam menjual unit produk Pepaya California. Mengingat Pepaya Sunfresh California ini adalah produk baru, maka diperlukan strategi dan usaha yang lebih offensive dibanding dengan produk lain yang telah ada dan telah terbentuk pasarnya. Strategi yang dilakukan 
untuk mencapai produktivitas tenaga penjualan adalah dengan memberikan target penjualan untuk masing-masing orang. Misalkan staf A diberikan target penjualan 100 krat per bulan dengan berat buah per krat nya adalah $18 \mathrm{~kg}$.

Penentuan target untuk masingmasing orang ini berdasarkan share yang berhasil didapatkan terhadap penjualan. Tenaga penjual dengan share penjualan paling besar akan memperoleh target paling besar pula. Adapun bagi tenaga penjual yang mampu melebihi target yang ditentukan akan memperoleh bonus sesuai dengan kelebihan penjualan yang dihasilkan.
Bonus dapat berupa 1,5 kali gaji atau penunjukan sebagai pengelola Grosir di Pasar Induk. Strategi ini diyakini akan mampu memotivasi tenaga penjual untuk lebih termotivasi dan lebih produktif tentunya.

\subsection{Performance Plan}

Dengan membuka pasar bagi produk Pepaya Sunfresh jenis California ini ke pasar tradisional kawasan Jabotabek, ditargetkan penerimaan pendapatan tahunan akan terus menerus naik dan diprediksi meningkat dari 35 milyar rupiah di tahun 2012 menjadi lebih dari 61 milyar rupiah di tahun 2014 (Tabel 13.).

Tabel 13.

Revenue Plan

\begin{tabular}{|c|c|c|c|}
\hline SSN & 2012 & 2013 & 2014 \\
\hline Market Demand & Rp 446.250.000.000,00 & Rp 474.300.000.000,00 & Rp 532.000.000.000,00 \\
\hline Market Share & $8 \%$ & $10 \%$ & $12 \%$ \\
\hline Sales Revenues & Rp 35.700.000.000,00 & Rp 48.378.600.000,00 & "Rp 61.712.000.000,00 \\
\hline Small Quantity & 2012 & 2013 & 2014 \\
\hline Market Demand & Rp 102.637.500.000,00 & Rp 109.089.000.000,00 & Rp 122.360.000.000,00 \\
\hline Market Share & $8 \%$ & $10 \%$ & $12 \%$ \\
\hline Sales Revenues & Rp 8.211.000.000,00 & Rp 11.127.078.000,00 & Rp 14.193.760.000,00 \\
\hline Revenue / Customer & $\mathrm{Rp} 38.369 .158,88$ & $\mathrm{Rp} 43.465 .148,44$ & $\mathrm{Rp} 46.083 .636,36$ \\
\hline Customer & 214 & 256 & 308 \\
\hline Large Quantity & 2012 & 2013 & 2014 \\
\hline Market Demand & Rp 343.612.500.000,00 & Rp 365.211.000.000,00 & Rp 409.640.000.000,00 \\
\hline Market Share & $8 \%$ & $10 \%$ & $12 \%$ \\
\hline Sales Revenues & Rp 27.489.000.000,00 & Rp 37.251.522.000,00 & Rp 47.518.240.000,00 \\
\hline Revenue / Customer & $\mathrm{Rp} 38.338 .912,13$ & $\mathrm{Rp} 47.213 .589,35$ & Rp 54.744.516,13 \\
\hline Customer & 717 & 789 & 868 \\
\hline
\end{tabular}

Segmen grosir adalah segmen yang lebih menguntungkan dibanding segmen retail sehingga ditargetkan penjualannya meningkat dari 27 milyar di tahun 2012 menjadi lebih dari 47 milyar rupiah di tahun 2014. Sedangkan segmen retail yang lebih sedikit jumlah pelanggannya dan lebih kecil profitabilitasnya ditargetkan mengalami peningkatan penjualan sebesar 8 milyar rupiah di tahun 2012 menjadi 14 milyar rupiah di tahun 2014.

\section{KESIMPULAN DAN SARAN}

\subsection{Kesimpulan}

Strategi pemasaran untuk pepaya Sunfresh jenis California grade B dan C adalah sebagai berikut : 
- Penentuan spesifikasi produk berdasar ukuran, kekotoran, warna kulit, kematangan, kemasan, dan berat.

- Penentuan harga relatif lebih tinggi dibanding pesaing yaitu Rp. 7.500 untuk retail dan Rp. 7.000 untuk grosir.

- Promosi below the line melalui penjual secara langsung.

- Lokasi penjualan di pasar tradisional Kawasan Jabotabek dg SEC B, B+ dan C.

- Pemberian training mengenai teknik menjual dan product knowledge bagi sales.

- Pengelompokan spesifikasi kelas saat sourcing.

- Pemberian seragam, kaos, mobile hanger, banner, poster, shelf strip.

- Penentuan target penjualan untuk masing-masing sales $\&$ bonus jika target tercapai.

- Penerimaan pendapatan diperkirakan meningkat dari 35 milyar rupiah di tahun 2012 menjadi lebih dari 61 milyar rupiah di tahun 2014.

\subsection{Saran}

Berikut adalah saran untuk perusahaan:

- Memahami benar karakteristik pelanggan yang berbeda berdasarkan jumlah pembelian dan harapan.

- Penetapan spesifikasi terhadap kualitas produk secara menyeluruh.

- Meningkatkan visibilitas merek dan awareness produk.

- Menganalisis dan memonitor pelaksanaan proyek Pepaya Sunfresh secara intens.

- Bagian sourcing perlu memastikan konsistensi suplai Pepaya California.

- Memilih supplier dengan hasil panen berkualitas dan harga yang bersaing yaitu Rp. 1,500-Rp. 2.000 per kilogram.
- Melakukan training pada petani mengenai cara penanaman dan perlakuan hasil panen yang benar.

- Seluruh departemen bersinergi demi mencapai tujuan (Interdepartement Integration).

- Seluruh target dapat tercapai jika seluruh elemen mampu bekerjasama dan strategi pemasaran yang direncanakan dijalankan dengan produktivitas yg optimal. 


\section{DAFTAR PUSTAKA}

Best, Roger J. 2009. Market-Based Management Strategies for Growing Customer Value and Profitability Fifth Edition. New Jersey: Pearson Education, Inc.

Bruns $\varnothing$, K., T.A. Fjord, and K.G. Grunert. 2002. Consumer"s food choice and quality perception. Mapp working paper 77. Aarhus: Aarhus School Business.

Biro Pusat Statistika (BPS) 2011. Data Luas Panen Pepaya Nasional, Data Produksi Pepaya Nasional, Produktivitas Pepaya Nasional.

Cooper, Robert G. 1993. Winning at New Products Accelerating the Process from Idea to Launch Second Edition. Canada: Addison-Wesley Publishing Company, Inc.

Cooper, Robert G. And Scott J. Edgett. 1999. Product Development for the Service Sector lesson from markets. New York: Perseus Books.

Depperin. Direktorat Jenderal Industri dan Agro Kimia. 2009. Roadmap Industri Pengolahan Buah di Indonesia.

Dimyati, Ahmad. 2005. The Marketing of Tropical Fruits Involving Small Growers in Indonesia. Presentation Slide. Dirjen Hortikultura Kementrian Pertanian Republik Indonesia.

Hidayati, Aprihatiningrum. 2011. Laporan Hasil Penelitian tentang Faktor-Faktor yang Mempengaruhi Keputusan Pembelian Pepaya California oleh Konsumen di Pasar Tradisional Kawasan Jabotabek. Jakarta: PPM School of Management.

Kotler, Philip and Kevin L. Keller. 2009. Marketing Management. 13th Edition. New Jersey: Pearson Prentice Hall.

Lovelock, Christopher and Jochen Wirtz. 2011. Service Marketing, People, technology, Strategy. Seventh edition. New Jersey: Perason Prentice Hall

Malhotra, N. K.. 2007. Marketing Research: An Applied Orientation. New Jersey: Pearson Education

Rahardi, F. 2000. Agribisnis Tanaman Buah. Jakarta: Penebar Swadaya.

Sobir, PhD. 2010. Sukses Bertanam Pepaya Unggul Kualitas Supermarket. Jakarta: Agro Media Pustaka

Laporan Akhir Riset Unggulan Strategis Nasional (RUSNAS). 2002. Pengembangan Buah-Buahan Unggulan Indonesia.

Laporan Penjualan Tahun Januari-Desember Per Penjualan, Per Aitem, Per Pelanggan Tahun 2010 PT Sewu Segar Nusantara.

Profil Perusahaan PT Sewu Segar Nusantara (SSN) Tahun 2011. 